Review Article

\title{
The importance of boron in biological systems
}

\author{
Irem Uluisik ${ }^{\mathrm{a}}$, Huseyin Caglar Karakaya ${ }^{\mathrm{a}}$, Ahmet Koc ${ }^{\mathrm{b}, *}$ \\ a Izmir Institute of Technology, Department of Molecular Biology and Genetics, 35430 Urla, Izmir, Turkey \\ b Inonu University, Medical School, Department of Medical Biology and Genetics, Battalgazi, Malatya, Turkey
}

\section{A R T I C L E I N F O}

\section{Keywords:}

Boron

Boric acid

Toxicity

Tolerance

Transport

\begin{abstract}
A B S T R A C T
Boron is an essential element for plants and probably essential for human and animal health. Boron has a broad range of physiological effects on biological systems at low concentrations, whereas it is toxic to at high concentrations. Eventhough there are many studies on boron's biological effects and toxicity, more information is needed to understand the mechanisms of its action. The aim of the current work is to review boron's function, transport and toxicity in different biological systems.
\end{abstract}

\section{General properties and chemistry of boron}

Boron is a metalloid located on group 13 in the periodic table with atomic number 5, atomic mass $10.811 \mathrm{~g} / \mathrm{mol}$ and chemical symbol $\mathrm{B}$. Although boron compounds have been known for centuries, it was first discovered as an element by Sir Humphry Davy and by Gay-Lussac and Thenard in 1808 [1].

Boron has different isotopes, among which ${ }^{10} \mathrm{~B}$ and ${ }^{11} \mathrm{~B}$ are the most stable ones. Boron is not present in an elemental form in nature, rather it forms organoboron complexes with sodium and oxygen, which are the physiologically important forms of boron in organisms [2]. Although boron has a low abundance when compared with the hydrogen, carbon, nitrogen, or oxygen, it is common in the environment and naturally found in rocks, soil, and water $[3,4]$.

Organoboron complexes, which contain B-O or B-N bonds like orthoborates, are important in biological systems. These organoboron complexes are formed in plant, animal, and human tissues. In an organism nearly $96 \%$ of the boron is present as an uncharged boric acid B $(\mathrm{OH})_{3}$ and as a small amount of borate anion $\mathrm{B}(\mathrm{OH})_{4}{ }^{-}[1,2,5]$. Boric acid is a weak Lewis acid with a $\mathrm{pKa}$ of 9.25 . This $\mathrm{pKa}$ value decreases when boron forms covalent bonds with its ligands, and it becomes negatively charged tetrahedral borate anion $\mathrm{B}(\mathrm{OH})_{4}{ }^{-}[2]$.

Both boric acid and borate make reversible interactions with biomolecules which contain adjacent cis-hydroxyl groups such as riboflavin, adenosine monophosphate, pyridoxine, pyrimidine nucleotides, ascorbic acid, and five carbon sugar molecules such as ribose, apiose, and polysaccharides. Borate also binds to $\mathrm{NAD}^{+}$in animals and affects its functions [6-9]. Such an affinity may be responsible for biological effects of boric acid [1]. Boric acid and the sodium salts of boron (borax, disodium tetraborate) are commonly used as an antiseptic, bactericide, cleaning agent such as soaps and detergents, preservatives, fire retardants, fertilizers, insecticides and herbicides. Boron is also used in many industrial applications including glass production, fiberglass insulation, porcelain enamel, ceramic glazes, and metal alloys $[3,10]$.

Major world boron deposits are located in Turkey and USA, and are also found in Argentina, Chile, Russia, China, Peru, Egypt, Iraq, Libya, Morocco and Syria [11].

\section{Boron requirement of microorganisms}

Boron has important roles in physiological and metabolic activities of microbial systems [11]. The first natural compound found to contain boron is the antibiotic Boromycin (produced by Streptomyces antibioticus) acting on gram-positive bacteria [12]. In addition, boron is present in the bacterial antibiotics tartrolons (produced by Sorangium cellulosum) [13,14], borophisin, aplasmomycin (produced by Streptomyces griseus) $[2,15,16]$; the bacterial quorum sensing molecule autoinducer AI-2 [17]; a boron containing siderophore vibrioferrin, which is produced by a marine bacterium [18]; and in borolithochromes, which are responsible for the pink color of the algae Solenopora jurassica [19].

Boron is required for bacterial nitrogen fixation in Azotobacter [20]. Bacillus boroniphilus requires boron for its growth and can tolerate more than $450 \mathrm{mM}$ boron [21]. Heterocystous cyanobacteria and actinomycetes of the genus Frankia also require boron for both growth and nitrogen fixation. Some species of Cyanobacteria contain heterocysts which are specific cells for nitrogen fixation. Boron was suggested to interact and stabilize the glycolipids of the heterocysts $[1,2,22,23]$.

Boron is also required for lower eukaryotes such as brown algae, diatoms and algal flagellates [2,24,25]. Additionally, the yeast

\footnotetext{
* Corresponding author at: Inonu University, School of Medicine, Department of Medical Biology and Genetics, 44280, Malatya, TURKEY.

E-mail address: ahmet.koc@inonu.edu.tr (A. Koc).
} 
Saccharomyces cerevisiae, which is a unicellular eukaryote, needs boron for its growth. Bennett showed that yeast cells can not divide under boron deficiency. When boron was added back to the media, yeast cells proliferated normally, however when the boron levels increased in the environment they could not grow well [26]. It has been also revealed that yeast can survive up to $80 \mathrm{mM}$ boric acid and it has been considered as a boron tolerant species. Yeast is a suitable model for investigating the molecular biology of the boron $[27,28]$.

\section{Boron roles in plants}

According to the Warington's report in 1923, growth of Vicia faba (field bean) was reduced in a medium that lacked boron, but when the medium was supplied with boron the growth was rescued [29]. Since that time boron has been accepted as a necessary and beneficial microelement for various organisms. In plants, boron is considered to have important roles in nucleic acid metabolism, carbohydrate and protein metabolism, cell wall synthesis, cell wall structure, membrane integrity and function, and phenol metabolism $[30,31]$. However, the molecular mechanisms of these functions are largely not known.

A primary function of boron at molecular level is that it cross-links pectins in plant cell walls. Pectins are complex polysaccharides and they are important components of plant cell wall structure. Borate forms a cross-link with apiose residues of pectin rhamnogalacturonanII (RG-II), which is essential for cell wall stability and normal leaf extension [32,33]. RG-II is a pectic polysaccharide which covalently binds to borate esters with cis-diol bounds [34]. Borate crosslinking in this pectic system strengthens cell wall physically and plays important roles in cell adhesion $[35,36]$.

In plants, boron has important roles in expanding organs, for this reason, the symptoms of boron deficiency can be mainly observed in expanding organs. Boron deficiency results in the formation of abnormal cell wall, altered cytoskeletal polymerization, and changes in plasma membrane permeability. In addition leaf expansion, root elongation, flower and fruit development are inhibited [4,37]. Boron deprivation interferes with many physiological processes such as sugar metabolism, carbohydrate metabolism, RNA metabolism, phenol metabolism, and cell wall structure $[4,38]$. In 2004, it was reported that the expression of glutathione S-transferase and glucosyltransferase was induced in tobacco (Nicotiana tabacum) BY-2 cells under boron limitation [39]. In 2009, another study with the same cells showed that oxidative damage was directly involved in cell death under boron deprivation and it was not likely a typical programmed cell death [40].

\section{Boron in human and animal health}

Boron and its compounds have been known for a while as beneficial for the metabolism of humans and animals. An essentiality of boron for human has not been reported, instead it is considered as a probably essential element by the WHO [41].

It has roles in steroid hormone metabolism, healthy bone development, and cell membrane maintenance $[11,42]$. People consume many products containing boron in their daily life; one can get 1-7 mg boron daily. It exists abundantly in vegetables, fruits, nuts, and their by-products $[43,44]$. In healthy people boron levels change between 15 and $80 \mu \mathrm{g} / \mathrm{kg}$ [45]. Boron is absorbed from gastrointestinal tract completely and present in body as boric acid [7].

In animals boron affects various mechanisms which include carbohydrate, mineral metabolism, energy consumption, regulation of several enzyme activities and embryonic development [11]. Boron deprivation affects the reproduction and development in organisms including frogs, zebrafish, rat, and mice [4,46-48]. It is also necessary during the embryonic development of zebra fish (Danio rerio) [49], rainbow trout (Oncorhynchus mykiss) [46] and frogs (Xenopus laevis) [47].

High amounts of boron are reported to interfere with the development of some organs of chicken and rat immune system [50]. It was found that long term excess boron intake of African ostrich Struthio camelus resulted in the resistance of thymus to boron stress [51]. It is known that boron is involved in inflammatory response by suppressing the activities of specific enzymes in some inflammatory diseases (joint swelling). 6-phosphogluconate, which is a pentose phosphate pathway constituent, forms complex with boron and subsequently inhibits 6phosphogluconate dehydrogenase enzyme in the same pathway. Pentose phosphate pathway is involved in the respiratory burst mechanism in which phagocytes need more oxygen due to the production of reactive oxygen species (ROS). Therefore, it is hypothesized that ROS production in leukocytes may be reduced through the inhibitory actions of boron on 6-phosphogluconate dehydrogenase so that the arthritic symptoms may be relaxed [7].

There are also studies suggesting the limiting effects of boron by inducing the antioxidant defense mechanisms that can destroy ROS $[52,53]$. Natural (i.e. sodium borate) and synthetic (i.e. peptide boronic acid) boron compounds have been shown to inhibit serine proteases such as chymotrypsin, cathepsin $\mathrm{G}$, elastase in a reversible manner in vitro $[7,54,55]$. The inhibition of serine proteases in coagulation system by boron, which is another way of action of boron in inflammatory response, has also been suggested [56]. The prostaglandins, leukotrienes, and thromboxanes are involved in the inflammation response and lipoxygenase is necessary for these components. This enzyme is inhibited by boron in cultured human leukocytes $[7,57,58]$.

Boron was also shown to regulate extracellular matrix by directly affecting the activities of some enzymes such as elastase, trypsin-like enzymes, collagenase. It also induces the release of TNF- $\alpha$ in fibroblasts [59]. Gene expression levels of some of the bone tissue related extracellular matrix proteins such as collagen type I (COLI), osteopontin (OPN), osteocalcin (OCN), bone sialoprotein (BSP) increase by boron treatment $[60,61]$. By the action of boron on extracellular matrix, it has been also suggested that boron may also improve the wound healing [62]. In one of the studies, it was reported that an antimicrobial hydrogel which contains boron was found to be successful in the healing of burn wound in in vitro [63].

The mineral part of bone is composed of mainly calcium and phosphate. Boron has been found beneficial for calcium metabolism and bone metabolism accordingly. Different metals in the bloodstream such as aluminum, boron, cadmium, chromium, and lead show an affinity to skeletal tissue during mineral removal of bone [61,64-66]. Boron is beneficial for the bone formation and composition especially in regulating the hormones that support the bone growth [61,67]. A study conducted with postmenopausal women showed that more boron intake causes more plasma estrogen and testosterone and less calcium excretion. In the postmenopausal period, bone loss was observed in women due to the reduced estrogen levels. Gallardo-Williams suggested that an increase of boron in diet resulted in an enhancement of plasma $17 \beta$-estradiol and testosterone levels and an impediment of calcium excretion in urine [65]. There are also supportive results from animal studies. For example, dietary supplementation of boron on pigs, chicken, and rats has shown to promote bone strength [65,68-70]. It was firstly proposed that boron has positive effects on bone mineralization in chickens that have Vitamin D deficient diet $[4,67]$.

There are several experimental and epidemiological studies showing the positive effects of boric acid on human prostate cancer cells $[6,42,71]$. When boric acid was supplemented in the diet of mice having impaired immune system, the human prostate cancer tumors that had been transplanted to mice showed decreased growth [72]. It also inhibits the growth and the proliferation of prostate cancer cell lines DU-145, and LNCaP in a dose dependent manner [49,73]. When considering the molecular markers of proliferation and senescence, boric acid was found to reduce the cyclin A-E, MAPK proteins and induce a senescent-like morphology rather than cell death in DU-145 cells [71]. Increased concentrations of boric acid were shown to bind NAD + and inhibit the NAD + induced Ca2 + release in DU-145 cells [6]. It was 
shown that boric acid can bind to cADRP (cyclic ADP ribose) which is an agonist of ryanodine receptor, when present in excess. It was proposed that boric acid binds to a site on the ryanodine receptor so that it can keep $\mathrm{Ca} 2+$ channel inactive $[74,75]$. When ER Ca2 + levels decrease due to the inactivation of $\mathrm{Ca} 2+$ channel; ER stress, formation of cytoplasmic stress granules, and eIF2 $\alpha$ /ATF4 pathway are induced accordingly in DU-145 prostate cells treated with physiological amounts of boric acid [76]. Studies also show that boric acid and phenylboronic acid affect the actin arrangement and thereby decrease the cell migration in DU-145 prostate cancer cells. Phenylboronic acid was found to be a more potent inhibitor of the cancer cell migration $[77,78]$.

There is also evidence that the intake of boron with the diet reduces the risks of lung and breast cancers in women [36,79]. Boric acid is effectively used in vaginal yeast infections especially caused by the dimorphic fungus Candida albicans [80]. Boric acid was shown to cause defects in cytokinesis and thus, the stabilization of cytoskeleton is impaired at bud neck in Saccharomyces cerevisae [81]. Unlike S. cerevisiae, the hyphal cytoskeleton was disrupted by boric acid in Candida albicans. It was suggested that boric acid exhibits these effects by impairing the actin organization in these yeasts [82].

Aflatoxins are produced by the fungus Aspergillus. They can contaminate food products and when consumed some of them have carcinogenic effects on animals and humans. It is suggested that boric acid has potential as a protective agent for DNA against oxidative damage caused by Aflatoxin B1 [83,84].

Boron deprivation results in impairment of growth, abnormal bone development, decrease in blood steroid hormone levels, increase in urinary calcium excretion, and changes in macromineral status in humans and animals [85]. It is also found that mice and frogs have developmental disorders arising from boron deficiency [86]. Boron deficiency was also shown to reduce osteogenesis in rat and mice models [87]. Boron has been known to play roles in the metabolism of other substances such as calcium, magnesium, triacylglycerols, glucose, amino acids, reactive oxygen species, hormones such as $17 \beta$-estradiol, calcitonin, 25-hydroxycholecalciferol [4,88].

Boron deprivation has been shown to cause photophobia which is photoreceptor dystrophy in the zebrafish $[4,46]$. In addition, it is found that in animals and humans, boron deficiency is also related to the decrease in the electrical activity of brain, short term memory, and decrease in skills in performing tasks whereas the boron supplementation increases brain functions. These effects of boron could be attributed to the changes in membranes providing nerve-impulse transmission by boron $[4,89,90]$. Boron deficiency is also suggested to be the possible causal agents in Kashin-Beck disease which is a bone disease having a high incidence in China [91].

\section{Boron toxicity and tolerance mechanisms}

Both boron deficiency and toxicity may have negative outcomes for the metabolism of plants and animals [92,93]. In general, metalloids lead to toxicity by affecting different cellular mechanisms in biological systems. The causes of metalloid toxicity can include an increase in oxidative system, DNA damage, impairment of DNA repair systems and membrane functions, or the inhibition of protein folding, protein function and activities. Cells develop various mechanisms to cope with this toxicity caused by metalloids such as export of the metalloid out of the cell, the storage of the metalloid in intracellular organelles, decrease of the import by the metalloid binding proteins and peptides [94-96].

Studies carried out to understand the molecular mechanisms of boron toxicity have revealed that there is a relation between the expression of boron efflux pump ATR1 and the expression of amino acid biosynthesis genes [97]. This mechanism is strictly regulated by the transcription factor Gcn 4 in response to boron stress. eIF $2 \alpha$ provides the delivery of charged methionyl initiator tRNA to the initiation codon and forms a ternary complex with GTP. It is a multimeric protein and is phoshorylated on serine-51 of its $\alpha$ subunit in response to viral infection, amino acid limitation, apoptosis, nutrient deprivation, heme deprivation, and other stresses [98]. Boron induces the phosphorylation of eIF $2 \alpha$ in a Gcn 2 protein kinase dependent manner, interferes with the initiation of translation, resulting in the inhibition of protein synthesis [97].

In addition, to find out the genes that play roles in boron metabolism, a haploid yeast deletion collection was screened for the genes that confer boron resistance or sensitivity to yeast cells. 21 boron sensitive and 6 boron resistant mutants were found. Additionally proteomic analyses showed that there are proteins whose expression increases in the presence of toxic levels of boric acid. All these genes and proteins indicate different pathways within the cell, which needs further investigation [99].

High concentrations of boron are generally used to control bacterial and fungal infections. The toxic activity of boric acid is suggested to be especially on mitochondria and mitochondrial enzymes in Saprolegnia which is a fungus and causes saprolegniasis in fish and fish eggs [100].

Boron may also be also toxic for humans. Humans consume boron daily, mostly from fruits and vegetables. When consumed at high doses, it can cause developmental and reproductive abnormalities [44]. A study on rats revealed that the lowest observed adverse effect level (LOAEL) of boron for developmental toxicity was $13.3 \mathrm{mg} / \mathrm{kg}$ body weight/day and the no observable adverse effect level (NOAEL) was $9.6 \mathrm{mg} / \mathrm{kg}$ body weight/day $[44,101]$. People who work in boron mine plants have a mean blood boron level of $224 \mathrm{ng} / \mathrm{g}$ and show no symptoms of toxicity [102]. Reports suggest that environmental or industrial boron exposure is not a treat for human health [103,104].

There is only limited number of cases for boron intoxication involving human subjects. Oral exposures of humans to high levels of boric acid have resulted in little or no observable toxicity, as seen in accidental poisonings up to $88 \mathrm{gr}$, of which $90 \%$ of the cases were asymptomatic [105]. Oral intake of boron by two infants resulted in anemia, seizures, erythema and scanty hair over several weeks [88]. A mid-age man who drank two cups of boric acid powder died on the third day of intake due to cardiac problems. His blood boron level was about $42 \mathrm{mg} / \mathrm{dL}$ after $52 \mathrm{~h}$ of intake [106]. However, gastrointestinal, cardiovascular, hepatic, renal, and central nervous system effects, dermatitis, erythema, and death have been observed in children and adults exposed to $\geq 84 \mathrm{mg}$ boron/ $\mathrm{kg}$ [106-109]. Chronic exposure to boron causes neurological effects, kidney damage, diarrhea, anorexia, weight loss, and testicular atrophy [88]. Based on the accidental poisoning results, acute lethal dose of boron is estimated to be around $20 \mathrm{~g}$ for adults.

Boron toxicity in plants is a relatively common issue in dry areas where soil boron levels are high. Some of the symptoms observed in boron toxicated plants are altered metabolism, lowered growth rates in shoots and roots, decreased levels of chlorophyll and lignin [110,111]. Boron most likely exerts its toxic activity in plants by either changing the cell wall structure or by binding to cis-diol containing sugars such as ribose moiety in metabolically important nucleotides [112].

\section{Boron uptake and transport mechanisms}

To maintain the boron homeostasis, boron levels that are transported inside or outside of the cell should be regulated by cellular mechanisms. The effects of boron can be observed primarily in plants since they are exposed to boron directly from the soil. Thus, many plant genes have been identified related to boron transport and tolerance mechanisms. Plants absorb boron from soil in the form of boric acid. It is taken up by roots and is loaded to xylem for transport to shoots. During this long distance transport boron follows the transpiration streams and accumulates at margins of mature leaves [113]. For the uptake of boron from the soil there are evidences for both passive and active transport. Boric acid is a small uncharged molecule and its volume $(71.5 \AA)$ is nearly the same as urea $(75.3 \AA)[4,110,114]$. The 
studies conducted with squash root (Cucurbita pepo) and charopyte alga (Chara corallina) [115] cells revealed that the permeability coefficient of boric acid for lipid bilayer is $8 \times 10^{-6} \mathrm{~cm} / \mathrm{s}$ [116,117]. Thus, under high boron supply, passive diffusion represents a significant way for boron to pass the root epidermis.

When availability of boron is low in the soil, there is a need for membrane proteins to uptake boron, which indicate the presence of active transport mechanisms. Many plant genes related to boron transport and tolerance, have been identified [118,119]. Boric acid is transported against its concentration gradient in sunflower (Helianthus annuus) in low boron conditions [120]. Similar to the sunflowers Arabidopsis thaliana accumulates boron in the xylem against a concentration gradient under boron limitation. BOR1, a boron efflux transporter, is responsible for this xylem loading [121]. A.thaliana bor1-1 mutant [122] can not translocate boron from roots to shoots thereby shoot growth can be inhibited under low boron conditions [123]. BOR1 is degraded in the vacuole following endocytosis when plants are exposed to high levels of boron [124]. BOR1 belongs to animal bicarbonate transporter superfamily (SLC4) and its homologs have been found in many organisms such as rice OsBOR1, yeast YNL275w, and mammalian NaBC1 [122,125,126].

Yeast has been used as a model organism for the characterization of many plant boron tolerant genes. Yeast BOR1 is localized to plasma membrane and has a role in boric acid efflux [127]. In addition to BOR1, DUR3 and FPS1 are found to be involved in boron tolerance in yeast. However, the functions of these transporters in boron detoxification are not clear [28]. ATR1 was found as the major boron tolerance gene in yeast [27]. It is composed of 14 membrane spanning domains and a member of the DHA2 family of drug- $\mathrm{H}+$ antiporters [128]. It reduces the intracellular boron levels and provides extreme resistance to boron [27]. Bioinformatics analyses showed that YMR279C and YOR378W were the two paralogs of ATR1 gene. The expression of YMR279C decreased the intracellular boron levels and provided remarkable boron resistance to the yeast cells [129]. NaBC1 is a voltage regulated bicarbonate sodium coupled borate cotransporter and it is identified as one of the BOR1 homologs in mammalian system and it improves the cell proliferation when boron concentrations are low $[75,126]$. AtBOR1 has six homologs in A. thaliana genome and only AtBOR4 shows tolerance to boron when overexpressed in A. thaliana under high boron conditions through boron efflux [31]. Besides $A$. thaliana, VvBOR1 and CmBOR1 have been characterized as boron transporters in Vitis vinifera and Citrus macrophylla [130,131]. In crop plants, BOT1, which is a BOR1 ortholog, provides boron tolerance to barley [132].

The membrane transport of boric acid is also facilitated by the special channel proteins, NIP5:1. NIP5:1 belongs to plant-specific nodulin 26-like intrinsic proteins (NIP) subfamily and has been identified as a boric acid channel that is upregulated in A. thaliana roots under boron deficiency [133]. It is also a member of major intrinsic protein family (MIP) proteins and serves as channels for water and small uncharged molecules in mammals, amphibians, yeast, bacteria and plants [134]. However, it is unclear whether other MIPs are involved in boric acid transport in animals. Vacuolar compartmentation of boron has been also reported in A. thaliana and Citrus macrophylla by the activity of TIP5, aquaporin family member localized in cell tonoplast membrane [135,136]. Overexpression of AtTIP5:1 lowers to boron concentration in cytoplasm by transferring boron to vacuole [136]. Vacuolar membrane proton pumps, especially tonoplast adenosine triphosphatase subunit E (V-ATPase E) and tonoplast pyrophosphatase (V-PPiase), change their expression under boron or salt toxicity $[137,138]$.

The information about physiology and molecular biology of boron uptake in humans and animals is limited. Boron is ingested from the diet [139]. It does not tend to accumulate in tissues. However bone, nails, and hair have been found to have higher boron levels, whereas fat tissue has low boron levels [140]. Boron is rapidly absorbed from the human intestine and then is excreted completely in the urine
$[4,44,65,141]$.

\section{Conclusions}

Boron occurs naturally in soils, rocks, and water bodies. In certain places of the World it is found at high concentrations. It is used commonly in agriculture due to its roles in plant growth and development. Boron deficiency and toxicity result in growth impairment in plants, which causes especially agricultural and economic loss in many parts of the World. Understanding the true mechanisms of boron action may improve crop yield.

Not only plants but also many organisms need boron for their metabolic activities. They have to acquire sufficient amounts of boron while protecting themselves from the toxic effects of it. For many years, boron has been used as a pesticide, antifungal and antimicrobial agent. Additional roles of boron have been revealed recently. For example, it has supporting roles in plant cell wall; it acts as a communicating signal molecule in quorum sensing mechanism.

Research on animal, plant, and cell cultures has showed that boron impairs the enzyme activities either directly or indirectly by binding to their cofactors (i.e. NAD) or in a way which is unknown yet $[2,142,143]$. Since it interferes with many metabolites, it can make changes in mineral and energy metabolisms both in humans and animals [4,144]. It has crucial roles in bone metabolism by interacting other minerals and vitamins such as calcium, magnesium and vitamin D and hormones which are important for bone formation [61,65,145]. It also reduces the risk of inflammatory diseases [4]. There are increasing evidences on the usage of boron in medicine. One of the supporting facts is the acceptance of bortezomib (Velcade ${ }^{\circ}$ ) which is a boron containing drug for the treatment of multiple myeloma by the US Food and Drug Administration (FDA). It acts as a reversible inhibitor of the proteosome in mammalian cells [146]. Accumulating evidences suggest that boron and boron containing molecules may offer to be natural anticancer agent or potential drugs in daily diet. However, for boron to become useful for the health, the mechanisms of its action and the risk of toxicity should be enlightened with new approaches both in vitro and in vivo.

\section{Acknowledgement}

This work was supported by TUBITAK grant no.110T917 to AK.

\section{References}

[1] L. Bolanos, K. Lukaszewski, I. Bonilla, D. Blevins, Why boron? Plant Physiol. Biochem. 42 (11) (2004) 907-912.

[2] C.D. Hunt, Dietary boron: an overview of the evidence for its role in immune function, J. Trace Elem. Exp. Med. 16 (4) (2003) 291-306.

[3] W.G. Woods, An introduction to boron - history, sources, uses, and chemistry, Environ. Health Perspect. 102 (1994) 5-11.

[4] F.S. Kot, Boron sources, speciation and its potential impact ob health, Rev. Environ. Sci. Bio/Technol. 8 (1) (2009) 3-28.

[5] T.A. Devirian, S.L. Volpe, The physiological effects of dietary boron, Crit. Rev. Food Sci. Nutr. 43 (2) (2003) 219-231.

[6] W.T. Barranco, D.H. Kim, S.L. Stella Jr., C.D. Eckhert, Boric acid inhibits stored Ca2 + release in DU-145 prostate cancer cells, Cell Biol. Toxicol. 25 (4) (2009) 309-320.

[7] C.D. Hunt, Regulation of enzymatic activity - one possible role of dietary boron in higher animals and humans, Biol. Trace Elem. Res. 66 (1-3) (1998) 205-225.

[8] D.H. Kim, B.N. Marbois, K.F. Faull, C.D. Eckhert, Esterification of borate with NAD $(+)$ and NADH as studied by electrospray ionization mass spectrometry and B-11 NMR spectroscopy, J. Mass Spectrom. 38 (6) (2003) 632-640.

[9] C.D. Hunt, Dietary boron: evidence for essentiality and homeostatic control in humans and animals, Adv. Plant Anim. Boron Nutr. (2007) 251-267.

[10] J.A. Moore, M. Callahan, R. Chapin, G.P. Daston, D. Erickson, E. Faustman, P. Foster, J.M. Friedman, L. Goldman, M. Golub, C. Hughes, R.J. Kavlock, C.A. Kimmel, J.C. Lamb, S.C. Lewis, C. Lunchick, S. Morseth, B.K. Mortensen, E.J. Oflaherty, A.K. Palmer, J. Ramlow, P.M. Rodier, K. Rudo, L. Ryan, B.A. Schwetz, A. Scialli, S. Selevan, R. Tyl, M. Campbell, E. Carney, W. Faber, J. Hellwig, S.R. Murphy, M.A. Smith, P.L. Strong, M. Weiner, An assessment of boric acid and borax using the IEHR evaluative process for assessing human developmental and reproductive toxicity of agents, Reprod. Toxicol. 11 (1) (1997) 
$123-160$.

[11] M. Tanaka, T. Fujiwara, Physiological roles and transport mechanisms of boron: perspectives from plants, Pflugers Arch.-Eur. J. Physiol. 456 (4) (2008) 671-677.

[12] R. Hütter, W. Keller-Schien, F. Knüsel, V. Prelog, G.C. Rodgers Jr., P. Suter, G. Vogel, W. Voser, H. Zähner, Stoffwechselprodukte von Mikroorganismen. 57. Mitteilung. Boromycin, Helv. Chim. Acta 50 (6) (1967) 1533-1539.

[13] H. Irschik, D. Schummer, K. Gerth, G. Hofle, H. Reichenbach, The tartrolons, new boron-containing antibiotics from a myxobacterium, Sorangium cellulosum, J. Antibiot. 48 (1) (1995) 26-30.

[14] D. Schummer, D. Schomburg, H. Irschik, H. Reichenbach, G. Hofle, Antibiotics from gliding bacteria. 75. Absolute configuration and biosynthesis of tartrolon B, a boron-containing macrodiolide from Sorangium cellulosum, Liebigs Annalen 6 (1996) 965-969.

[15] T. Rezanka, K. Sigler, Biologically active compounds of semi-metals, Phytochemistry 69 (3) (2008) 585-606.

[16] H. Nakamura, Y. Iitaka, T. Kitahara, T. Okazaki, Y. Okami, Structure of aplas momycin, J. Antibiot. 30 (9) (1977) 714-719.

[17] X. Chen, S. Schauder, N. Potier, A. Van Dorsselaer, I. Pelczer, B.L. Bassler, F.M. Hughson, Structural identification of a bacterial quorum-sensing signal containing boron, Nature 415 (6871) (2002) 545-549.

[18] S.A. Amin, F.C. Kupper, D.H. Green, W.R. Harris, C.J. Carrano, Boron binding by a siderophore isolated from marine bacteria associated with the toxic dinoflagellate Gymnodinium catenatum, J. Am. Chem. Soc. 129 (3) (2007) 478-479.

[19] K. Wolkenstein, J.H. Gross, H. Falk, Boron-containing organic pigments from a Jurassic red alga, Proc. Natl. Acad. Sci. U. S. A. 107 (45) (2010) 19374-19378.

[20] G.R. Anderson, J.V. Jordan, Boron, A non-essential growth factor for Azotobacter chroococcum, Soil Sci. 92 (2) (1961) 113-116.

[21] I. Ahmed, A. Yokota, T. Fujiwara, A novel highly boron tolerant bacterium, Bacillus boroniphilus sp nov., isolated from soil, that requires boron for its growth, Extremophiles (2007) 217-224.

[22] I. Bonilla, M. Garciagonzalez, P. Mateo, Boron requirement in cyanobacteria - its possible role in the early evolution of photosynthetic organisms, Plant Physiol. 94 (4) (1990) 1554-1560.

[23] P. Mateo, I. Bonilla, E. Fernandezvaliente, E. Sanchezmaeso, Essentiality of boron for dinitrogen fixation in Anabaena sp PCC 7119, Plant Physiol. 81 (1986) $430-433$.

[24] J. Lewin, C.-H. Chen, Effects of boron deficiency on chemical composition of a marine diatom, J. Exp. Bot. 27 (5) (1976) 916-921.

[25] J. McLachlan, Effects of nutrients on growth and development of embryos of Fucus edentatus Pyl (Phaeophyceae, Fucales), Phycologia 16 (3) (1977) 329-338.

[26] A. Bennett, R.I. Rowe, N. Soch, C.D. Eckhert, Boron stimulates yeast (Saccharomyces cerevisiae) growth, J. Nutr. 129 (12) (1999) 2236-2238.

[27] A. Kaya, H.C. Karakaya, D.E. Fomenko, V.N. Gladyshev, A. Koc, Identification of a novel system for boron transport: Atr1 is a main boron exporter in yeast, Mol. Cell. Biol. 29 (13) (2009) 3665-3674.

[28] A. Nozawa, J. Takano, M. Kobayashi, N. von Wiren, T. Fujiwara, Roles of BOR1, DUR3, and FPS1 in boron transport and tolerance in Saccharomyces cerevisiae, FEMS Microbiol. Lett. 262 (2) (2006) 216-222.

[29] K. Warington, The effect of boric acid and borax on the broad bean and certain other plants, Ann. Bot. 37 (1923) 629-672.

[30] H.E. Goldbach, M.A. Wimmer, Boron in plants and animals: is there a role beyond cell-wall structure? J. Plant Nutr. Soil Sci.-Zeitschrift Fur Pflanzenernahrung Und Bodenkunde 170 (1) (2007) 39-48.

[31] K. Miwa, J. Takano, H. Omori, M. Seki, K. Shinozaki, T. Fujiwara, Plants tolerant of high boron levels, Science 318 (5855) (2007) 1417-1417.

[32] M. Kobayashi, T. Matoh, J. Azuma, Two chains of rhamnogalacturonan II are cross-linked by borate-diol ester bonds in higher plant cell walls, Plant Physiol. 110 (3) (1996) 1017-1020.

[33] M.A. O'Neill, T. Ishii, P. Albersheim, A.G. Darvill, I.I. Rhamnogalacturonan, Structure and function of a borate cross-linked cell wall pectic polysaccharide, Annu. Rev. Plant Biol. 55 (2004) 109-139.

[34] W.S. York, A.G. Darvill, M. McNeil, P. Albersheim, Structure of plant-cell walls. 16. 3-deoxy-D-manno-2-octulosonic acid (KDO) is a component of rhamnogalacturonan-II, a pectic polysaccharide in the primary-cell walls of plants, Carbohydr. Res. 138 (1) (1985) 109-126.

[35] T. Ishii, T. Matsunaga, Chemical structure and function of the plant cell wall polysaccharide rhamnogalacturonan II, Mokuzai Gakkaishi 49 (3) (2003) $153-160$.

[36] R. Scorei, Is boron a prebiotic element? A mini-review of the essentiality of boron for the appearance of life on earth, Origins Life Evol. Biospheres 42 (1) (2012) $3-17$.

[37] B. Dell, L.B. Huang, Physiological response of plants to low boron, Plant Soil 193 (1-2) (1997) 103-120.

[38] A.J. Parr, B.C. Loughman, Boron and membrane function in plants, Metals and Micronutrients, Uptake Util. Plants (1983) 87-107.

[39] M. Kobayashi, T. Mutoh, T. Matoh, Boron nutrition of cultured tobacco BY-2 cells. IV. Genes induced under low boron supply, J. Exp. Bot. 55 (401) (2004) 1441-1443.

[40] T. Koshiba, M. Kobayashi, T. Matoh, Boron nutrition of tobacco BY-2Cells. V. oxidative damage is the major cause of cell death induced by boron deprivation, Plant Cell Physiol. 50 (1) (2009) 26-36.

[41] W.H. Organization, Trace Elements in Human Nutrition and Health, (1996), pp $0-361$.

[42] Y. Cui, M.I. Winton, Z.F. Zhang, C. Rainey, J. Marshall, J.B. De Kernion, C.D. Eckhert, Dietary boron intake and prostate cancer risk, Oncol. Rep. 11 (4) (2004) 887-892.
[43] S.J. Baker, J.W. Tomsho, S.J. Benkovic, Boron-containing inhibitors of synthetases, Chem. Soc. Rev. 40 (8) (2011) 4279-4285.

[44] M.V. Pahl, B.D. Culver, P.L. Strong, F.J. Murray, N.D. Vaziri, The effect of pregnancy on renal clearance of boron in humans: a study based on normal dietary intake of boron, Toxicol. Sci. 60 (2) (2001) 252-256.

[45] W.B. Clarke, C.E. Webber, M. Koekebakker, R.D. Barr, Lithium and boron in human blood, J. Lab. Clin. Med. 109 (2) (1987) 155-158.

[46] C.D. Eckhert, Boron stimulates embryonic trout Growth, J. Nutr. 128 (12) (1998) 2488-2493.

[47] D.J. Fort, T.L. Propst, E.L. Stover, P.L. Strong, F.J. Murray, Adverse reproductive and developmental effects in Xenopus from insufficient boron, Biol. Trace Elem. Res. 66 (1-3) (1998) 237-259.

[48] L. Lanoue, M.W. Taubeneck, J. Muniz, L.A. Hanna, P.L. Strong, F.J. Murray, F.H. Nielsen, C.D. Hunt, C.L. Keen, Assessing the effects of low boron diets on embryonic and fetal development in rodents using in vitro and in vivo model systems, Biol. Trace Elem. Res. 66 (1-3) (1998) 271-298.

[49] R.I. Rowe, C.D. Eckhert, Boron is required for zebrafish embryogenesis, J. Exp. Biol. 202 (12) (1999) 1649-1654.

[50] Q. Hu, S. Li, E. Qiao, Z. Tang, E. Jin, G. Jin, Y. Gu, Effects of boron on structure and antioxidative activities of spleen in rats, Biol. Trace Elem. Res. 158 (1) (2014) 73-80.

[51] H.-b. Huang, K. Xiao, S. Lu, K.-l. Yang, A.R. Ansari, H. Khaliq, J. Song, H.-z. Liu, K.M. Peng, Increased thymic cell turnover under boron stress may bypass TL/4 pathway in african ostrich, PLoS One 10 (6) (2015).

[52] C.D. Hunt, J.L. Herbel, J.P. Idso, Dietary boron modifies the effects of exercise training on bone and energy substrate metabolism in the rat, FASEB J. 7 (3) (1993) A204-A204.

[53] S.P. Spielberg, J.D. Butler, K. Macdermot, J.D. Schulman, Treatment of glutathione synthetase deficient fibroblasts by inhibiting gamma-glutamyl transpeptidase activity with serine and borate, Biochem. Biophys. Res. Commun. 89 (2) (1979) 504-511.

[54] C.A. Bauer, G. Petterss, Effect of boric-acid on catalytic activity of Streptomycesgriseus protease 3, Eur. J. Biochem. 45 (2) (1974) 473-477.

[55] C.A. Kettner, A.B. Shenvi, Inhibition of the serine proteases leukocyte elastase, pancreatic elastase, cathepsin-G, and chymotrypsin by peptide boronic acids, J. Biol. Chem. 259 (24) (1984) 5106-5114.

[56] C.D. Hunt, Dietary boron enhances the beneficial effects of exercise training on bone calcium, phosphorus, and magnesium concentrations in the rat, FASEB J. 12 (4) (1998) A205.

[57] A. Belver, J.P. Donaire, Partial-purification of soluble lipoxygenase of sunflower cotyledons - action of boron on the enzyme and lipid constituents, Zeitschrift Fur Pflanzenphysiologie 109 (4) (1983) 309-317.

[58] K.G. Rajendran, S.Y. Chen, A. Sood, B.F. Spielvogel, I.H. Hall, The anti-osteoporotic activity of amine-carboxyboranes in rodents, Biomed. Pharm. 49 (3) (1995) 131-140.

[59] M. Benderdour, T. Van Bui, K. Hess, A. Dicko, F. Belleville, B. Dousset, Effects of boron derivatives on extracellular matrix formation, J. Trace Elem. Med. Biol. 14 (3) (2000) 168-173.

[60] M. Dzondo-Gadet, R. Mayap-Nzietchueng, K. Hess, P. Nabet, F. Belleville, B. Dousset, Action of boron at the molecular level - effects on transcription and translation in an acellular system, Biol. Trace Elem. Res. 85 (1) (2002) 23-33.

[61] S.S. Hakki, B.S. Bozkurt, E.E. Hakki, Boron regulates mineralized tissue-associated proteins in osteoblasts (MC3T3-E1), J. Trace Elem. Med. Biol. 24 (4) (2010) 243-250.

[62] R.M. Nzietchueng, B. Dousset, P. Franck, M. Benderdour, P. Nabet, K. Hess, Mechanisms implicated in the effects of boron on wound healing, J. Trace Elem. Med. Biol. 16 (4) (2002) 239-244.

[63] S. Demirci, A. Dogan, E. Karakus, Z. Halici, A. Topcu, E. Demirci, F. Sahin, Boron and poloxamer (F68 and F127) containing hydrogel formulation for burn wound healing, Biol. Trace Elem. Res. 168 (1) (2015) 1-12.

[64] F. Bronner, B.M. Slepchenko, M. Pennick, S.J.P. Damment, A model of the kinetics of lanthanum in human bone, using data collected during the clinical development of the phosphate binder lanthanum carbonate, Clin. Pharmacokinet. 47 (8) (2008) 543-552.

[65] M.T. Gallardo-Williams, R.R. Maronpot, C.H. Turner, C.S. Johnson, M.W. Harris, M.J. Jayo, R.E. Chapin, Effects of boric acid supplementation on bone histomorphometry, metabolism, and biomechanical properties in aged female F-344 rats, Biol. Trace Elem. Res. 93 (1-3) (2003) 155-169.

[66] T.J. McCoy, I.M. Steele, K. Keil, B.F. Leonard, M. Endress, Chladniite, NA2CAMG7(PO4)6 -a new mineral from the Carlton (IIICD) iron meteorite, Am. Miner. 79 (3-4) (1994) 375-380.

[67] F.H. Nielsen, The emergence of boron as nutritionally important throughout the life cycle, Nutrition 16 (7-8) (2000) 512-514.

[68] T.A. Armstrong, W.L. Flowers, J.W. Spears, F.H. Nielsen, Long-term effects of boron supplementation on reproductive characteristics and bone mechanical properties in gilts, J. Anim. Sci. 80 (1) (2002) 154-161.

[69] R.E. Chapin, W.W. Ku, M.A. Kenney, H. McCoy, The effects of dietary boric acid on bone strength in rats, Biol. Trace Elem. Res. 66 (1-3) (1998) 395-399.

[70] C.D. Hunt, F.H. Nielsen, Effects of dietary boron on bone calcification in magnesium and cholecalciferol deficient chicks, Fed. Proc. 46 (3) (1987) 754-754.

[71] W.T. Barranco, C.D. Eckhert, Cellular changes in boric acid-treated DU-145 prostate cancer cells, Br. J. Cancer 94 (6) (2006) 884-890.

[72] M.T. Gallardo-Williams, R.E. Chapin, P.E. King, G.J. Moser, T.L. Goldsworthy, J.P. Morrison, R.R. Maronpot, Boron supplementation inhibits the growth and local expression of IGF-1 in human prostate adenocarcinoma (LNCaP) tumors in nude mice, Toxicol. Pathol. 32 (1) (2004) 73-78. 
[73] W.T. Barranco, C.D. Eckhert, Boric acid inhibits human prostate cancer cell proliferation, Cancer Lett. 216 (1) (2004) 21-29.

[74] P. Chameau, Y. Van de Vrede, P. Fossier, G. Baux, Ryanodine-, IP3- and NAADPdependent calcium stores control acetylcholine release, Pflugers Arch.-Eur. J. Physiol. 443 (2) (2001) 289-296.

[75] K. Henderson, S.L. Stella, Jr., S. Kobylewski, C.D. Eckhert, Receptor activated $\mathrm{Ca} 2+$ release is inhibited by boric acid in prostate cancer cells, PLoS One 4 (6) (2009).

[76] K.A. Henderson, S.E. Kobylewski, K.E. Yamada, C.D. Eckhert, Boric acid induces cytoplasmic stress granule formation, eIF2 alpha phosphorylation, and ATF4 in prostate DU-145 cells, Biometals 28 (1) (2015) 133-141.

[77] T.M. Bradke, C. Hall, S.W. Carper, G.E. Plopper, Phenylboronic acid selectively inhibits human prostate and breast cancer cell migration and decreases viability, Cell Adhes. Migr. 2 (3) (2008) 153-160.

[78] E.M. McAuley, T.A. Bradke, G.E. Plopper, Phenylboronic acid is a more potent inhibitor than boric acid of key signaling networks involved in cancer cell migration, Cell Adhes. Migr. 5 (5) (2011) 382-386.

[79] S. Mahabir, M.R. Spitz, S.L. Barrera, Y.Q. Dong, C. Eastham, M.R. Forman, Dietary boron and hormone replacement therapy as risk factors for lung cancer in women, Am. J. Epidemiol. 167 (9) (2008) 1070-1080.

[80] C. Iavazzo, I.D. Gkegkes, I.M. Zarkada, M.E. Falagas, Boric acid for recurrent vulvovaginal candidiasis: the clinical evidence, J. Womens Health 20 (8) (2011) 1245-1255.

[81] M. Schmidt, J.Z. Schaumberg, C.M. Steen, M.P. Boyer, Boric acid disturbs cell wall synthesis in Saccharomyces cerevisiae, Int. J. Microbiol. 2010 (2010) 1-10.

[82] B.R. Pointer, M.P. Boyer, M. Schmidt, Boric acid destabilizes the hyphal cytoskeleton and inhibits invasive growth of Candida albicans, Yeast 32 (4) (2015) 389-398.

[83] H. Turkez, A. Tatar, A. Hacimuftuoglu, E. Ozdemir, Boric acid as a protector against paclitaxel genotoxicity, Acta Biochim. Pol. 57 (1) (2010) 95-97.

[84] K.A. Guindon, L.L. Bedard, T.E. Massey, Elevation of 8-hydroxydeoxyguanosine in DNA from isolated mouse lung cells following in vivo treatment with aflatoxin B-1, Toxicol. Sci. 98 (1) (2007) 57-62.

[85] F.J. Murray, A human health risk assessment of boron (boric acid and borax) in drinking water, Regul. Toxicol. Pharm. 22 (3) (1995) 221-230.

[86] J.J. Heindel, C.J. Price, E.A. Field, M.C. Marr, C.B. Myers, R.E. Morrissey, B.A. Schwetz, Developmental toxicity of boric-acid in mice and rats, Fundam. Appl. Toxicol. 18 (2) (1992) 266-277.

[87] A.A. Gorustovich, T. Steimetz, F.H. Nielsen, M.B. Guglielmotti, Histomorphometric study of alveolar bone healing in rats fed a boron-deficient diet, Anat. Rec.-Adv. Integr. Anat. Evol. Biol. 291 (4) (2008) 441-447.

[88] F.H. Nielsen, Boron in human and animal nutrition, Plant Soil 193 (1-2) (1997) 199-208.

[89] J.G. Penland, Dietary boron, brain-function, and cognitive performance, Environ. Health Perspect. 102 (1994) 65-72.

[90] J.G. Penland, The importance of boron nutrition for brain and psychological function, Biol. Trace Elem. Res. 66 (1-3) (1998) 299-317.

[91] X. Peng, L.X. Zeng, G.N. Schrauzer, G. Xiong, Selenium, boron, and germanium deficiency in the etiology of Kashin-Beck disease, Biol. Trace Elem. Res. 77 (3) (2000) 193-197.

[92] C. Yazbeck, W. Kloppmann, R. Cottier, J. Sahuquillo, G. Debotte, G. Huel, Health impact evaluation of boron in drinking water: a geographical risk assessment in Northern France, Environ. Geochem. Health 27 (5-6) (2005) 419-427.

[93] J.J. Camacho-Cristobal, J. Rexach, A. Gonzalez-Fontes, Boron in plants: deficiency and toxicity, J. Integr. Plant Biol. 50 (10) (2008) 1247-1255.

[94] J.A. Lemire, J.J. Harrison, R.J. Turner, Antimicrobial activity of metals: mechanisms, molecular targets and applications, Nat. Rev. Microbiol. 11 (6) (2013) $371-384$.

[95] N. Verbruggen, C. Hermans, H. Schat, Mechanisms to cope with arsenic or cadmium excess in plants, Curr. Opin. Plant Biol. 12 (3) (2009) 364-372.

[96] M.J. Tamas, S.K. Sharma, S. Ibstedt, T. Jacobson, P. Christen, Heavy metals and metalloids as a cause for protein misfolding and aggregation, Biomolecules 4 (1) (2014) 252-267.

[97] I. Uluisik, A. Kaya, D.E. Fomenko, H.C. Karakaya, B.A. Carlson, V.N. Gladyshev, A. Koc, Boron stress activates the general amino acid control mechanism and inhibits protein synthesis, PLoS One 6 (11) (2011).

[98] S.R. Kimbal, Eukaryotic initiation factor eIF2, Int. J. Biochem. Cell Biol. 31 (1) (1999) 25-29.

[99] I. Uluisik, A. Kaya, E.S. Unlu, K. Avsar, H.C. Karakaya, T. Yalcin, A. Koc, Genomewide identification of genes that play a role in boron stress response in yeast, Genomics 97 (2) (2011) 106-111.

[100] S.E. Ali, E. Thoen, O. Evensen, J. Wiik-Nielsen, A.A.A. Gamil, I. Skaar, Mitochondrial dysfunction is involved in the toxic activity of boric acid against saprolegnia, PLoS One 9 (10) (2014).

[101] C.J. Price, M.C. Marr, C.B. Myers, J.C. Seely, J.J. Heindel, B.A. Schwetz, The developmental toxicity of boric acid in rabbits, Fundam. Appl. Toxicol. 34 (2) (1996) 176-187.

[102] Y. Duydu, N. Başaran, H.M. Bolt, Exposure assessment of boron in Bandırma boric acid production plant, J. Trace Elem. Med. Biol. 26 (2-3) (2012) 161-164.

[103] B.S. Sayli, An assessment of fertility in boron-exposed Turkish subpopulations 2. Evidence that boron has no effect on human reproduction, Biol. Trace Elem. Res. 66 (1-3) (1998) 409-422.

[104] B.S. Sayli, E. Tuccar, A.H. Elhan, An assessment of fertility in boron-exposed Turkish subpopulations, Reprod. Toxicol. 12 (3) (1998) 297-304.

[105] T.L. Litovitz, W. Klein-Schwartz, G.M. Oderda, B.F. Schmitz, Clinical manifestations of toxicity in a series of 784 boric acid ingestions, Am. J. Emerg. Med. 6 (3)
(1988) 209-213.

[106] A. Restuccio, M.E. Mortensen, M.T. Kelley, Fatal ingestion of boric acid in an adult, Am. J. Emerg. Med. 10 (6) (1992) 545-547.

[107] B.M. Schillinger, M. Berstein, L.A. Goldberg, A.R. Shalita, Boric acid poisoning, J. Am. Acad. Dermatol. 7 (5) (1982) 667-673.

[108] Y. Ishii, N. Fujizuka, T. Takahashi, K. Shimizu, A. Tuchida, S. Yano, T. Naruse, T. Chishiro, A fatal case of acute boric acid poisoning, Journal of Toxicology, Clin. Toxicol. 31 (2) (1993) 345-352.

[109] L.C. Wong, M.D. Heimbach, D.R. Truscott, B.D. Duncan, Boric acid poisoning, Can. Med. Assoc. J. 90 (17) (1964) 1018-1023.

[110] R.O. Nable, G.S. Banuelos, J.G. Paull, Boron toxicity, Plant Soil 193 (1-2) (1997) 181-198.

[111] R. Reid, Identification of boron transporter genes likely to be responsible for tolerance to boron toxicity in wheat and barley, Plant Cell Physiol. 48 (12) (2007) 1673-1678.

[112] R.J. Reid, J.E. Hayes, A. Post, J.C.R. Stangoulis, R.D. Graham, A critical analysis of the causes of boron toxicity in plants, Plant Cell Environ. 27 (11) (2004) $1405-1414$.

[113] P.H. Brown, B.J. Shelp, Boron mobility in plants, Plant Soil 193 (1-2) (1997) 85-101.

[114] H.N. Hu, P.H. Brown, Absorption of boron by plant roots, Plant Soil 193 (1-2) (1997) 49-58.

[115] J.C.R. Stangoulis, R.J. Reid, P.H. Brown, R.D. Graham, Kinetic analysis of boron transport in Chara, Planta 213 (1) (2001) 142-146.

[116] C. Dordas, P.H. Brown, Permeability of boric acid across lipid bilayers and factors affecting it, J. Membr. Biol. 175 (2) (2000) 95-105.

[117] J.A. Raven, Short-distance and long-distance transport of boric-acid in plants, New Phytol. 84 (2) (1980) 231-249.

[118] Y. Kato, K. Miwa, J. Takano, M. Wada, T. Fujiwara, Highly boron deficiency-tolerant plants generated by enhanced expression of NIP5, a boric acid channel, Plant Cell Physiol. 50 (1) (2009) 58-66.

[119] J. Takano, K. Miwa, T. Fujiwara, Boron transport mechanisms: collaboration of channels and transporters, Trends Plant Sci. 13 (8) (2008) 451-457.

[120] F. Dannel, H. Pfeffer, V. Romheld, Compartmentation of boron in roots and leaves of sunflower as affected by boron supply, J. Plant Physiol. 153 (5-6) (1998) 615-622.

[121] J. Takano, K. Noguchi, M. Yasumori, M. Kobayashi, Z. Gajdos, K. Miwa, H. Hayashi, T. Yoneyama, T. Fujiwara, Arabidopsis boron transporter for xylem loading, Nature 420 (6913) (2002) 337-340.

[122] J. Takano, K. Noguchi, H. Hayashi, T. Fujiwara, Arabidopsis Thaliana Mutant Bor1-1 Is Defective in Boron Translocation, (2002).

[123] K. Miwa, J. Takano, T. Fujiwara, Improvement of seed yields under boron-limiting conditions through overexpression of BOR1, a boron transporter for xylem loading, in Arabidopsis thaliana, Plant J. 46 (6) (2006) 1084-1091.

[124] J. Takano, K. Miwa, L.X. Yuan, N. von Wiren, T. Fujiwara, Endocytosis and degradation of BOR1, a boron transporter of Arabidopsis thaliana, regulated by boron availability, Proc. Natl. Acad. Sci. U. S. A. 102 (34) (2005) 12276-12281.

[125] Y. Nakagawa, H. Hanaoka, M. Kobayashi, K. Miyoshi, K. Miwa, T. Fujiwara, Celltype specificity of the expression of os BOR1, a rice efflux boron transporter gene, is regulated in response to boron availability for efficient boron uptake and xylem loading, Plant Cell 19 (8) (2007) 2624-2635.

[126] M. Park, Q. Li, N. Shcheynikov, W.Z. Zeng, S. Muallem, NaBC1 is a ubiquitous electrogenic $\mathrm{Na}+$-coupled borate transporter essential for cellular boron homeostasis and cell growth and proliferation, Mol. Cell 16 (3) (2004) 331-341.

[127] J. Takano, M. Kobayashi, Y. Noda, T. Fujiwara, Saccharomyces cerevisiae Bor1p is a boron exporter and a key determinant of boron tolerance, FEMS Microbiol. Lett. 267 (2) (2007) 230-235.

[128] Y. Gbelska, J.J. Krijger, K.D. Breunig, Evolution of gene families: the multidrug resistance transporter genes in five related yeast species, FEMS Yeast Res. 6 (3) (2006) 345-355.

[129] G.O. Bozdag, I. Uluisik, G.S. Gulculer, H.C. Karakaya, A. Koc, Roles of ATR1 paralogs YMR279c and YOR378w in boron stress tolerance, Biochem. Biophys. Res. Commun. 409 (4) (2011) 748-751.

[130] P. Canon, F. Aquea, A. Rodriguez-Hoces de la Guardia, P. Arce-Johnson, Functional characterization of Citrus macrophylla BOR1 as a boron transporter, Physiol. Plant. 149 (3) (2013) 329-339.

[131] R. Perez-Castro, K. Kasai, F. Gainza-Cortes, S. Ruiz-Lara, J.A. Casaretto, H. PenaCortes, J. Tapia, T. Fujiwara, E. Gonzalez, VvBOR1, the grapevine ortholog of AtBOR1, encodes an efflux boron transporter that is differentially expressed throughout reproductive development of Vitis vinifera L, Plant Cell Physiol. 53 (2) (2012) 485-494.

[132] T. Sutton, U. Baumann, J. Hayes, N.C. Collins, B.J. Shi, T. Schnurbusch, A. Hay, G. Mayo, M. Pallotta, M. Tester, P. Langridge, Boron-toxicity tolerance in barley arising from efflux transporter amplification, Science 318 (5855) (2007) 1446-1449.

[133] J. Takano, M. Wada, U. Ludewig, G. Schaaf, N. von Wiren, T. Fujiwara, The Arabidopsis major intrinsic protein NIP5;1 is essential for efficient boron uptake and plant development under boron limitation, Plant Cell 18 (6) (2006) 1498-1509.

[134] I.S. Wallace, W.-G. Choi, D.M. Roberts, The structure, function and regulation of the nodulin 26-like intrinsic protein family of plant aquaglyceroporins, Biochim. Biophys. Acta-Biomembr. 1758 (8) (2006) 1165-1175.

[135] M.-R. Martinez-Cuenca, B. Martinez-Alcantara, A. Quiones, M. Ruiz, D.J. Iglesias, E. Primo-Millo, M. Angeles Forner-Giner, Physiological and molecular responses to excess boron in citrus macrophylla W, PLoS One 10 (7) (2015).

[136] Y. Pang, L. Li, F. Ren, P. Lu, P. Wei, J. Cai, L. Xin, J. Zhang, J. Chen, X. Wang, 
Overexpression of the tonoplast aquaporin AtTIP5;1 conferred tolerance to boron toxicity in Arabidopsis, J. Genet. Genomics 37 (6) (2010) 389-U52.

[137] A.E. Atik, G.O. Bozdag, E. Akinci, A. Kaya, A. Koc, T. Yalcin, H.C. Karakaya, Proteomic changes during boron tolerance in barley (Hordeum vulgare) and the role of vacuolar proton-translocating ATPase subunit E, Turk. J. Bot. 35 (4) (2011) 379-388.

[138] M. Hanitzsch, D. Schnitzer, T. Seidel, D. Golldack, K.-J. Dietz, Transcript level regulation of the vacuolar $\mathrm{H}+$-ATPase subunit isoforms VHA-a, VHA-E and VHA$\mathrm{G}$ in Arabidopsis thaliana, Mol. Membr. Biol. 24 (5-6) (2007) 507-518.

[139] R.F. Moseman, Chemical disposition of boron in animals and humans, Environ. Health Perspect. 102 (1994) 113-117.

[140] W.W. Ku, R.E. Chapin, R.F. Moseman, R.E. Brink, K.D. Pierce, K.Y. Adams, Tissue disposition of boron in male Fischer rats, Toxicol. Appl. Pharmacol. 111 (1) (1991) 145-151.
[141] C.D. Hunt, Biochemical effects of physiological amounts of dietary boron, J. Trace Elem. Exp. Med. 9 (4) (1996) 185-213.

[142] C.J. Lovatt, L.M. Bates, Early effects of excess boron on photosynthesis and growth of Cucurbito-pepo, J. Exp. Bot. 35 (152) (1984) 297-305.

[143] P.P. Power, W.G. Woods, The chemistry of boron and its speciation in plants, Plant Soil 193 (1-2) (1997) 1-13.

[144] F.H. Nielsen, The justification for providing dietary guidance for the nutritional intake of boron, Biol. Trace Elem. Res. 66 (1-3) (1998) 319-330.

[145] F.H. Nielsen, The alteration of magnesium, calcium and phosphorus metabolism by dietary magnesium deprivation in postmenopausal women is not affected by dietary boron deprivation, Magnes. Res. 17 (3) (2004) 197-210.

[146] R.C. Kane, P.F. Bross, A.T. Farrell, R. Pazdur, Velcade((R)): USFDA approval for the treatment of multiple myeloma progressing on prior therapy, Oncologist 8 (6) (2003) 508-513. 